\title{
Managing leaf-cutting ants: peculiarities, trends and challenges
}

\author{
Terezinha MC Della Lucia, ${ }^{a *}$ Lailla C Gandra ${ }^{b}$ and Raul NC Guedes ${ }^{b}$
}

\begin{abstract}
Leaf-cutting ants are generally recognized as important pest species in Neotropical America. They are eusocial insects that exhibit social organization, foraging, fungus-cultivation, hygiene and a complex nest structure, which render their management notoriously difficult. A lack of economic thresholds and sampling plans focused on the main pest species preclude the management of leaf-cutting ants; such management would facilitate their control and lessen insecticide overuse, particularly the use of insecticidal baits. Recent restrictions on the use of synthetic compounds for such purposes impose additional challenges for the management of leaf-cutting ants. Considerable effort has been exerted regarding these challenges, which are addressed herein, but which also remain challenges that are yet to be conquered.
\end{abstract}

(c) 2013 Society of Chemical Industry

Keywords: Acromyrmex; ant baits; Atta; control; control shortcomings; management problems

\section{LEAF-CUTTING ANTS: FROM LA FONTAINE TO SAINT-HILAIRE AND BEYOND}

Ants are widely known for their remarkable evolutionary developments that are frequently portrayed in popular tales, fables, aphorisms and films. The frugal ant of Jean de la Fontaine (La Cigale et la Fourmi; Fable II, BookI) illustrates one of these characteristics: evolved labor culminating in practices that are analogous to modern human agriculture, such as storage. Although describing agriculture-like cultivation by ants, Aesop's Fables explores a different aspect, which emphasizes their characterization as 'thieves' (or pests).

The abundance and economic importance of leaf-cutting ants were well recognized by the French naturalist Auguste de SaintHilaire in his visit to the then Province of São Paulo (Brazil) in the 19th century, during which he stated that 'either Brazil annihilates the leaf-cutting ants, or the leaf-cutting ants will annihilate Brazil'. This statement became a benchmark for Brazilians and allowed the leaf-cutting ants to metaphorically embody other eventual enemies of the country and its people, including domestic politicians. This perception and the unsavory reputation of the leaf-cutting ants in Brazil (and elsewhere) are also illustrated by Macunaíma, the Brazilian (anti-)hero deprived of any character created by the writer Mário de Andrade (Macunaíma; 1928), who mockingly stated that '... little health, lots of leaf-cutting ants, the banes of Brazil are...'. In fact, public health in Brazil has experienced much improvement since the 1920s; however, leafcutting ants are still a concern, not only in Brazil, but also in the entire Neotropical region. Their management has not advanced much and currently faces trying scenarios not only in Brazil, but in all other countries where they occur, including, Argentina, Colombia, Peru and Venezuela.

The problems with leaf-cutting ants have been aggravated in planted forest ecosystems. These sites are huge extensions of monocultures (mainly Eucalyptus) where leaf-cutting ants are key pests. Forestry companies face problems such as restrictive certification requirements, and a lack of control agents and techniques to keep these pests below economic thresholds. All these issues motivated this review.

\subsection{Species and defining traits}

The members of the Myrmicine, tribe Attini (Hymenoptera: Formicidae) exhibit a unique trait among the ants - the cultivation of fungi as a food source. Whereas the lower genera of the tribe use varied substrates for this cultivation, the higher genera cultivate fungi on freshly cut vegetation, which explains why they are widely referred to as leaf-cutting ants and are thought to have reached the apogee of instinct through agriculture. ${ }^{1}$ The leaf-cutting ants are native to the Neotropics and belong to two genera: Atta and Acromyrmex. ${ }^{2,3}$

Leaf-cutting ants are eusocial or 'truly' social insects, and are characterized by three traits: (1) cooperative brood care, (2) reproductive division of labor, and (3) overlapping generations of stages that contribute to colony labor. ${ }^{4,5}$ Polymorphism, polyphenism and polyethism exist within leaf-cutting ants, illustrating the complexity of their colony's social organization. A colony is formed by the queen (which is wingless), winged males and females (occurring at discreet reproductive periods) and workers. $^{6}$ This structure allows efficient division of labor within the colony, thereby including brood care and hygiene in addition to fungus-cultivation, among other behaviors, and

\footnotetext{
* Correspondence to: Terezinha Maria C Della Lucia, Departamento de Biologia Animal, Universidade Federal de Viçosa, Viçosa, MG 36570-000, Brazil. E-mail:tdlucia@ufv.br

a Departamento de Biologia Animal, Universidade Federal de Viçosa, Viçosa, MG 36570-000, Brazil

b Departamento de Entomologia, Universidade Federal de Viçosa, Viçosa, MG 36570-000, Brazil
} 
demands structural nest complexity and social interaction to allow the coexistence of up to millions of individuals within a single colony.

\subsection{Importance: hero, villain or in between?}

Leaf-cutting ants are the dominant species in both natural and human-disturbed settings where they occur, and are considered to be a keystone species because of their influence on the environment; these ants contribute largely to environmental diversity, productivity, and nutrient and energy flow. ${ }^{7,8}$ More recently, leaf-cutting ants have been regarded as ecosystem engineers because they modulate, directly and indirectly, resource availability to other species by changing the physical state of biotic and abiotic materials. ${ }^{9-13}$ Their activity modifies soil properties by improving aeration, drainage and root penetration, and by increasing organic matter and nutrient mineralization and availability. ${ }^{14-19}$ Secondary seed dispersal and improved germination by manipulation have also been associated with the activity of leaf-cutting ants, ${ }^{20,21}$ and their symbiotic relationships have led to recent antibiotic discoveries, including candicidin and dentigerumicin. ${ }^{22,23}$ In addition, leaf-cutting ant colonies are considered to be models for designing improved agricultural management for sustainable production. ${ }^{24}$

The notoriety of leaf-cutting ants as pests is in startling contrast to their environmental importance and benefits. This apparent paradox is not difficult to understand in areas where leaf-cutting ants are native, however, given that these ants are recognized as pests of human-altered environments (e.g. agriculture and reforestation fields), but not of natural environments; such recognition is rooted in the alleged threat that they pose to an investment (namely that involving agriculture or forest production), which may surpass an economic threshold (equivalent to control costs). By contrast, there is no paradox in areas where leaf-cutting ants are invasive. For example, in Guadeloupe (French West Indies), leaf-cutting ants were widely spread after failures in control attempts soon after they reached the island. Now they are threatening plant species in protected areas, in particular rain forest arborescent ferns of Cyathea sp. ${ }^{25}$ The overall magnitude of the losses caused by the ants' foraging activity supports their pest status within agriculture and man-established forests in the Neotropics. Approximate global estimates of economic losses caused by leaf-cutting ants reach billions of dollars, and these estimates are deemed to be conservative. ${ }^{26,27}$

Single defoliation events in Eucalyptus can reduce tree diameter by $11 \mathrm{~mm}$ and height by $0.7 \mathrm{~m}$, causing a 13\% loss in wood volume at the end of a 7-year cycle. ${ }^{28}$ In addition, successive defoliations compromise tree growth and shape, and the yield of cultivated tree species such as Eucalyptus and pine. ${ }^{29,30}$ The end result is that an estimated $30 \%$ of plantation management expenses are devoted to the control of leaf-cutting ants. ${ }^{31}$ Annual consumption by a mature colony of Atta bisphaerica, a grass-cutter, is estimated to be $\sim 3$ tons of sugarcane, totaling $450 \mathrm{~kg}$ of sugar or $300 \mathrm{~L}$ of alcohol, and a loss of US\$ 60 million. ${ }^{32}$ The virtually continuous availability of suitable food sources for leaf-cutting ants in areas where they occur further emphasizes their status as pest species. These examples involve direct costs; however, indirect costs, such as increased likelihood of erosion due to clearing around the nest, potential damage to cattle and machinery, and construction damage due to nest excavation and foraging, should not be neglected. ${ }^{33,34}$

Leaf-cutting ants may have various benefits and/or losses. Regarding losses and the status of these ants as pests, however, we may allude to George Orwell's pigs (Animal Farm, 1945) and mention that all leaf-cutting ants are equal, but some are more equal than others. Among the 15 species of Atta and 35 species of Acromyrmex with their many subspecies, only some 9 or 10 species have broad economic importance as pests (Table 1). 7,35,36 Therefore, concern regarding leaf-cutting ants as pest species should focus on a limited number of species and on fields in which economic loss indeed occurs.

\section{LEAF-CUTTING ANT PECULIARITIES AND MANAGEMENT LIMITATIONS}

Leaf-cutting ants exhibit a series of adaptations, namely social organization, foraging, fungus-cultivation, hygiene and a complex nest structure that render their management difficult. Such adaptations make these insects unique and, because of these adaptations, control methods for their management are also distinct from those usually required for insect pest management in agriculture, cultivated forests and pastures. We will subsequently address these general adaptations and emphasize their control limitations.

\subsection{Social organization}

The social organization and complexity of leaf-cutting ants are largely responsible for the high colony efficiency observed among these insects. The colony acts as a superorganism with a long-living queen: the key individual that is both responsible for the colony's structure and viability, which are sustained by its reproductive output. The remaining members of the colony are formed by her progeny, including the winged males and females that will eventually leave the colony to form new ones, and the workers (in their distinct subdivisions), which perform the various tasks within the colony (e.g. brood care, queen attendance, foraging, colony defense and waste disposal). Therefore, control practices that are targeted at individuals other than the queen have a smaller chance of success unless their suppression or impairment: (1) has a strong and direct (negative) impact on the queen's survival, or (2) is sufficiently great to hinder replacement by the queen, thus compromising colony sustainability.

Control agents, either biological or chemical, face a different requirement in the control of leaf-cutting ants. In both control types, high direct mortality is usually the objective, but even high mortality of foraging workers is unlikely to achieve colony suppression. Therefore, biological and chemical control agents that target the queen herself or substantially impact a caste associated with brood care and queen (or fungus) attendance are more likely to succeed. Such agents are more difficult to obtain and also explain the lack of applied biological control against leaf-cutting ants. A limited portfolio of insecticide options is used against these species, which are mainly restricted to sulfluramid and fipronil, although chlorpyrifos, deltamethrin and even diflubenzuron, among a few other compounds, are also used. ${ }^{27,28,37}$ Other control methods, including queen removal and physical destruction of the colony, are limited to small areas and to ants with small and superficial colonies such as young Atta colonies and some of Acromyrmex. ${ }^{27,38}$

\subsection{Foraging and fungus cultivation}

Another important peculiarity of leaf-cutting ants involves foraging for the provision of fresh leaves to be used in a fungus-cultivated garden. Regarding herbivory, these ants are 


\begin{tabular}{|c|c|c|c|c|}
\hline \multirow[b]{2}{*}{ Genus } & \multirow[b]{2}{*}{ Species } & \multirow[b]{2}{*}{ Foraging substrate } & \multicolumn{2}{|c|}{ Distribution } \\
\hline & & & Continent & Main countries \\
\hline \multirow[t]{4}{*}{ Atta } & A. capiguara & Monocots & South America & Brazil \\
\hline & A. cephalotes & Dicots & $\begin{array}{l}\text { North, Central and } \\
\text { South America }\end{array}$ & $\begin{array}{l}\text { Brazil, Colombia, Ecuador, French } \\
\text { Guiana, Guyana, Mexico, } \\
\text { Nicaragua, Peru, Suriname, } \\
\text { Venezuela }\end{array}$ \\
\hline & A. laevigata & Monocots and dicots & South America & Brazil and Venezuela \\
\hline & A. sexdens & Dicots & South America & $\begin{array}{l}\text { Argentina, Brazil, French Guiana, } \\
\text { Paraguay, Peru, Suriname, } \\
\text { Venezuela }\end{array}$ \\
\hline \multirow[t]{6}{*}{ Acromyrmex } & Ac. balzani & Monocots & South America & $\begin{array}{l}\text { Argentina, Bolivia, Brazil, Paraguay, } \\
\text { Venezuela }\end{array}$ \\
\hline & Ac. octospinosus & Dicots & $\begin{array}{l}\text { North, Central and } \\
\text { South America }\end{array}$ & $\begin{array}{l}\text { Brazil, Colombia, French Guiana, } \\
\text { Mexico, Venezuela }\end{array}$ \\
\hline & Ac. rugosus & Dicots & South America & $\begin{array}{l}\text { Argentina, Bolivia, Brazil, Paraguay, } \\
\text { Peru }\end{array}$ \\
\hline & Ac. subterraneus brunneus & Dicots & South America & Brazil and Peru \\
\hline & Ac. subterraneus molestans & Monocots and dicots & South America & Brazil \\
\hline & Ac. subterraneus subterraneus & Dicots & South America & Argentina, Brazil and Paraguay \\
\hline
\end{tabular}

among the most polyphagous and voracious insects known. ${ }^{11,39}$ Curiously, however, they exhibit unexpected selectivity in their harvesting choices to provision the fungus garden. The ants appear to manage their leaf sources while foraging, and exhibit noticeable behavioral plasticity in their foraging decisions. ${ }^{11,40-45}$ Some consequences of such foraging habits include the increased foraging area of individual colonies, which threatens cultivated fields away from the colony nest, the higher risk of attack in homogeneous plantations, and the rejection of insecticidal and pathogen-contaminated baits. ${ }^{39,46-50}$

The history of agriculture in Attini ants most likely had a single origin some 50 million years ago, after the separation of South America from Africa. ${ }^{51}$ The 'superior agriculture' developed by the higher Attini (i.e., the leaf-cutting ants) is based on the use of freshly cut leaves to cultivate the highly 'domesticated' fungus, which was the target of various adaptations that led to their mutualistic association. ${ }^{1,51-54}$ The fungus is the main food source for the ants, and these fungi belong to two genera of basidiomycetes: Leucoagaricus and Leucocoprinus (Agaricaceae: Leucocoprinae). ${ }^{51,55}$ Fungal transmission is colony-dependent for its clonal propagation (within the colony itself) and for the formation of new colonies via dispersion by winged females during the ants' nuptial flight. ${ }^{53,56}$ The integrity of the fungus garden is paramount to colony survival, and its jeopardy leads to colony suppression and, therefore, to the control of leafcutting ants, which poses a challenge. Physical destruction of the colonies and fungus garden contamination are possibilities for control, particularly in small and shallow ant colonies. However, the physical destruction of the colony is costly, and reaching the fungus garden with a contaminant, particularly a biological contaminant (e.g. a pathogen or competitor), is difficult due to the social structure and hygiene practices performed by leaf-cutting ants when securing their garden maintenance and yield.

\subsection{Hygiene}

The intricacies of farming and living under high colony density in leaf-cutting ants are rather complex, involving multiple microorganism interactions (not only with the cultivated fungus) and high levels of hygiene (worthy models for human metropolises)..$^{57-60}$ Leaf-cutting ants are able to maintain continuous monocultural fungus-cultivation without perceivable production disasters - a feat that modern human agriculture accomplishes with frequent threats and disaster. These ants have apparently been able to accomplish such a feat because of their ability to associate hygienic strategies with social complexity involving: (1) the use of mixed chemicals from exocrine glands (mainly the metapleural glands), (2) the use of antimicrobials from mutualistic bacteria (Pseudonocardia) cultured on the ants' exoskeleton (as observed in Acromyrmex), (3) waste disposal compartmentalization and management, and (4) communication and nestmate (and even fungus) recognition within a structured society. ${ }^{57,61-70}$

The metabolites produced by the ant mutualistic bacteria Pseudonocardia are usually regarded as narrow-spectrum antimicrobials, which are active against Escovopsis, a specialized and occasionally virulent fungus that is able to attack and devastate species of cultivated ant fungus. ${ }^{63,65}$ However, Escovopsis is not the only threat to the fungus garden, and generalist pathogens may also attack both the symbiont fungus and the leaf-cutting ants. ${ }^{63,64}$ Such a threat is managed with exocrine gland secretions from the ants, primarily from their metapleural glands, which exhibit broadspectrum antimicrobial activity. ${ }^{71-73}$ Recent findings indicate that elaborate metapleural gland secretions and reduced reliance on Pseudonocardia prevail in larger colonies of leaf-cutting ants, thus emphasizing the difficulties of efficiently managing disease in large societies with general chemical mixtures versus specific bacterial antimicrobials as potential tools for such tasks. ${ }^{69}$

Pathogens are not the only threat to the fungus garden, and a suitable microclimate is also necessary for the desired cultivation and yield; leaf-cutting ants are able to relocate their gardens to suitable nest chambers and to heavily invest in building, repairing and maintaining nest structure. ${ }^{74,75}$ In addition, fungus-cultivation generates large amounts of degraded plant material, which are frequently contaminated with fungal competitors and other microorganisms that are potentially detrimental to the garden 
and the colony. ${ }^{22,75-77}$ The containment of these waste products in isolated internal nest chambers or external piles, away from the fungus garden, aided by hygienic behaviors (e.g. grooming and strict labor division to minimize contact with contaminants) guarantees high levels of hygiene and minimizes the potential risks to the fungus garden and to colony survival. ${ }^{57,67,78,79}$ Nestmate and even fungus recognition further aid in such efforts by the colony. ${ }^{61,66,68}$ The high levels of care and sanitation exhibited by leaf-cutting ants cause constraints in the use of a substrate with either pathogens or insecticides, thereby preventing these control agents from reaching key castes or the entire colony.

\subsection{Nest structure}

The nest structure of leaf-cutting ants is a reflection of their fungus-cultivation habits and social organization, which sometimes reaches extremely high levels of complexity in architectural achievements rivaling those of China's Great Wall; this phenomenon was recently explored in a newspaper section from the Daily Mail. ${ }^{80}$ However, the levels of nest complexity vary among species, with species of Atta exhibiting larger, deeper and more intricate designs than Acromyrmex that involve myriad underground tunnels, deposits and interconnected chambers. ${ }^{81-83}$ Furthermore, nest construction and maintenance are dynamic, and leaf-cutting ants are able to minimize flooding problems by raising chambers above risk levels, to counterbalance high $\mathrm{CO}_{2}$ levels by opening new nest ventilation orifices, to prevent noxious gas from spreading by shutting down tunnels, and even to recycle waste materials to repair nest damage when feasible and necessary. ${ }^{75,84-87}$ Consequently, the management practice of the physical destruction of large leaf-cutting ant nests is doomed to failure; fumigation and/or thermal fogging require sufficient gas distribution and careful dosing to achieve the desired effect.

\section{TRENDS IN LEAF-CUTTING ANT MANAGEMENT}

The history of leaf-cutting ant control encompasses a broad array of methods ranging from domestic techniques to physical and biological control methods, including the use of a diverse set of chemicals from inorganic compounds, such as sulfur and lime, to old chlorinated compounds (e.g. aldrin, chlordane and dodecachlor), fumigants, traditional organosynthetic compounds of broad use (e.g. organophosphate, carbamates and pyrethroids) to more modern substances (e.g., sulfluramid and fipronil). Curiously though, control, and not management, of leaf-cutting ants is generally the goal, and a basic economic threshold for the management of these species is noticeably lacking, with control decisions usually based on empirical observations. ${ }^{88,89}$ Prompted by increased concern and studies aimed at determining economic injury levels of leaf-cutting ants, a welcome change in approach seems to be occurring. Cultivated Eucalyptus seem to be the focus of attention regarding this effort, and economic injury levels in the range of $13.4-39.2 \mathrm{~m}^{2} \mathrm{ha}^{-1}$ of nest (based on the number and area of nests in a given field) have been suggested..$^{90,91}$ These thresholds will provide a foundation for the proper management of leaf-cutting ants rather than the current prevailing empirical control-making decision.

The management tactics (or control methods) under recent scrutiny will be emphasized with their potential practical suitability against leaf-cutting ants. Regretably, efficacy data on methods alternative to insecticide use are scarce and variable. Reliable efficacy data, however, are available for chemical control with sulfluramid (insecticidal) baits providing high levels of efficacy (ranging from 83.3 to $100.0 \%$ ) against leaf-cutting ants attacking broad-leaf species, ${ }^{92-94}$ efficacy range also reached with thermal fogging. ${ }^{95}$ Nonetheless, the chemical control of leaf-cutting ants also faces several constraints, which will be addressed.

\subsection{Environmental manipulation of the cultivated field}

Physical, mechanical and cultural control methods are frequently discussed independent of one another, and such methods are used at different levels against leaf-cutting ants, particularly in small areas that are attacked by small colonies in superficial nests. Some examples of control practices within these categories include the removal of queens, compost treatments (i.e. nest coverage with a mix of organic and inorganic ingredients after removal of the nest top soil) and physical nest destruction. ${ }^{27}$ The efficacy of such methods, however, is dubious and not always subjected to rigorous testing. By contrast, the cumulative evidence gathered suggests that the diversification of crop systems has management potential against these ants. ${ }^{27}$

The diversification of crop systems, such as the conservation of undergrowth vegetation in Eucalyptus plantations and/or the maintenance of strips of native vegetation in the field, allows a wider variety of foraging plants, thereby minimizing the risk of attack to the main plant species, especially if well-known attractive alternatives are available. ${ }^{26,38,39,41}$ Furthermore, crop system diversification allows for increased diversity of natural enemies that are likely to limit colony expansion and the establishment of higher density colonies. ${ }^{96-98}$

\subsection{Biological control}

Natural biological control of leaf-cutting ants seems to be generally favored by the diversification of crop systems, as previously discussed. In addition, the use of applied biological control is usually encouraged because of its perceived rationality, sustainability and environmental friendliness; unfortunately, however, biological control agents do have potential environmental risks and should be carefully studied before eventual recommendation and use, particularly in cases of exotic species in classical biocontrol efforts. ${ }^{99-102}$

Phoridae flies compose the main group of biological control agents under scrutiny. ${ }^{103,104}$ The phorid parasitoid flies that frequently attack leaf-cutting ants primarily belong to the genera Apocephalus (Brown), Eibesfeldtphora (Disney) and Myrmosicarius (Disney). These parasitoids lay their eggs either in foraging workers transporting leaves along the trail or while these workers are cutting leaf fragments. ${ }^{105-108}$ However, the ants are not passive hosts and exhibit a generalized response to phorid attacks. ${ }^{108}$ In addition, the attack by such natural enemies is unlikely to suppress the colony, which is the same shortcoming shared by other biocontrol agents of leaf-cutting ants; this phenomenon is one of the main reasons why little progress has been achieved in such control programs.

The use of pathogens against leaf-cutting ants seems to be a more promising biocontrol tactic, which has been the target of more investigation and use with emphasis on Metarhizium anisopliae (Metsch.) and Beauveria bassiana (Balsamo) infecting the ants, and Trichodermaspp. antagonizing antcultivated fungus. $27,109,110$ However, the promising laboratory results that are usually obtained with these pathogens are not translated into field effectiveness. ${ }^{27,111}$ This lack of effectiveness 
might be due to a wide range of possibilities, including stability of the pathogen formulation and the efficacy of the delivery system, but the remarkable resilience of ants against the use of field pathogens is more likely to be due to their capacity to detect, defend and recover from their exposure to these control agents, which are greatly limited in laboratory settings.

\subsection{Insecticides, repellents and pheromones}

Insecticide application prevails against leaf-cutting ants throughout their area of occurrence as pest species in four distinct practices - powder application, fumigation, thermal fogging and toxic baiting. The application of dry powder formulations is achieved by pumping the insecticide into the nest via its main opening and active orifices. Organophosphates, carbamates and particularly pyrethroids have been used as dry powder to provide efficient control under dry environmental conditions and against small and shallow nests. ${ }^{33,37}$ Deep and complex nest structures, as usually observed in mature nests of Atta, are not amenable to this practice because the powder will not reach more protected chambers housing the queen, its brood and the minor workers that look after these insects, thus failing to suppress the colony.

The use of fumigants (i.e. gas insecticide), primarily methyl bromide, was often previously employed against leaf-cutting ants. The compound was directly applied to the nest (again via open and active orifices), passing from liquid to gas upon the release of pressure. As a gas, the compound is able to spread throughout the nest, thereby causing its suppression. However, in addition to its high mammal toxicity, methyl bromide is an ozone layerdepleting substance that is being phased out as agreed upon in the Montreal Protocol. ${ }^{112}$ Therefore, methyl bromide is no longer an option against leaf-cutting ants, and no substitute is currently available.

Thermal fogging of insecticides is another management alternative used against these pests. This involves the use of thermal foggers to heat up diesel or mineral oil to generate the 'fog' in which the insecticide is suspended and thus disseminated. To suppress large colonies (with over $10 \mathrm{~m}^{2}$ of surface diameter), such a technique requires fog application into active nest openings until the nest is saturated. ${ }^{111}$ Thermal foggers have been the target of improvement, and their application against leaf-cutting ants remains useful, although granular toxic baits are the main method of insecticide use because of their relatively low cost, high efficacy and generally low environmental impact (when properly used). In addition, fog dispersion in complex nests is relatively slow, potentially allowing tunnel blocking by the ants preventing the fog-applied insecticide from reaching key nest chambers.

Toxic baits containing attractants to leaf-cutting ants have widespread use, and sulfluramid and fipronil are the main compounds currently under large-scale use. ${ }^{111,113}$ The baits are distributed near the ant trails and nest openings; the quantity of bait is based on the nest size, and the ants pick up the granules and introduce them into the nest. Until its prohibition, dodecachlor was the compound of choice in the early use of toxic baits. ${ }^{37,114,115}$ The high persistence of this organochloride and its low acute toxicity to foraging workers are the likely causes of its success in toxic baits. The harvested baits are taken into the nest, thus contaminating the fungus garden and allegedly also the minor workers when they are handling the fungus, which causes their eventual death within four to five days. ${ }^{114-116}$ The wholesale death of this caste affects fungus-cultivation, resulting in colony starvation. ${ }^{116}$ Sulfluramid has largely replaced dodecachlor in toxic baits, although fipronil

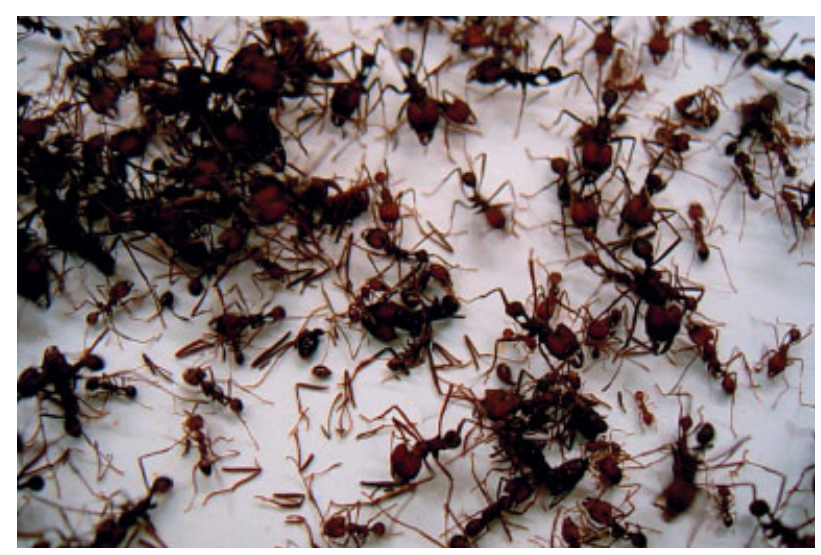

Figure 1. Representative pattern of nestmate aggression with mutilated ants and body parts sparked by $\beta$-eudesmol among workers of leaf-cutting ants (Atta sexdens).

and a few other compounds are also employed. ${ }^{27,111,117}$ However, the mechanisms of colony suppression by these compounds are poorly known. Some alternatives, such as abamectin, also proved to be effective in colony suppression by directly impairing the queen's fertility, but its slow activity ( $\sim 9$ weeks) prevents its commercial use. ${ }^{117,118}$

Among the new pesticides under development, biopesticides or biorational pesticides have received considerable attention. ${ }^{19,120}$ Again, these compounds' presumed environmental safety and problems of the evolution of resistance to synthetic insecticides have attracted attention. Plant extracts are at the forefront of current research on insecticidal compounds for use in baits. ${ }^{121-124}$ Curiously, it is frequently neglected that chemical structure, and not origin (either natural or synthetic), determines the physical-chemical properties and consequently the toxicity of a given compound, and that leaf-cutting ants notably lack recorded problems of insecticide resistance with the exception of one doubtful account in Atta sexdens from Paraguay from the 1960s. ${ }^{125,126}$

Natural products have had and continue to have crop protection value both as per se insecticides or as chemical backbones for new insecticide molecules, but these products are still limited by the same concerns and shortcomings as synthetic compounds. Some natural compounds, particularly from plant extracts (unlike others, such as lime stone), ${ }^{124}$ show promise against leaf-cutting ants in laboratory experiments, either affecting the ants themselves or their cultivated fungus. ${ }^{121-123,127-131}$ However, their potential for field use still deserves attention because, for example, high vapor pressure as in the $\beta$-eudesmol, a bioactive compound from an Eucalyptus clone effective against leaf-cutting ants, 129,130 precludes such use despite its potent interference with nestmate recognition; such interference leads to aggression and high mortality among nestmates (Fig. 1). ${ }^{129,131}$

Compounds that modulate behavior are also objects of attention against leaf-cutting ants, and, among these, natural repellents show promise. Some plants and plant extracts, as recently recognized in the Programme of Applied Research to Popular Medicine in the Caribbean (TRAMIL), initiated in 1982, do exhibit repellence to leaf-cutting ants and may prove useful in association with cultivated plants, thereby diversifying the crop system and minimizing the risk of attack. ${ }^{39,42,122}$ Another approach against leaf-cutting ants that was developed and explored between the mid-1970s and late 1980s was to increase bait pick-up 
(bait contaminated with pathogens or toxic compounds) to improve their field efficacy due to the potentially reduced exposure of the bait to environmental conditions and improved attractiveness. ${ }^{132-134}$ Brood, trail and alarm pheromones were tested by being impregnated into small sachets containing granulated baits, but the results were disappointing. ${ }^{132,134}$

\section{CHALLENGES FOR MANAGING LEAF-CUTTING ANTS}

The management of leaf-cutting ants is not short of challenges, some of which were previously addressed while discussing their peculiarities and their management limitations and also while addressing the current trends in leaf-cutting ant management.

Physical, mechanical and cultural control strategies against leaf-cutting ants are limited and generally used in small areas, with restriction (a good review on these methods can be found in Montoya-Lerma et al.). ${ }^{27}$ All alternative methods to the chemical control of leaf-cutting ants per se can be considered a challenge because much still has to be done before they can be recommended for large-scale use. In this section, the focus is on four specific challenges that have an impact on those already discussed.

\subsection{Applying integrated pest management to leaf-cutting ants}

The basic tenets of integrated pest management are the integration of a range of practices (or tactics) to contain pest population levels below the economic injury level, where the cost of the control tactic equals the economic loss caused by the pest infestation. Although the integration of control tactics against leafcutting ants requires improvement, the availability of economic injury levels against these species is lacking. Experimentally based sampling procedures and schemes to assess ant population levels to allow decision-making with such thresholds are virtually nonexistent. The establishment of economic injury levels for Eucalyptus plantations has recently been the target of attention, and the effort seems to be advancing. ${ }^{90,91}$ The development of sampling plans suitable for decision-making, however, lags far behind with very limited research effort. ${ }^{135,136}$

Among reforestation companies in Brazil, for instance, empirical methods prevail, and the so-called 'worst focus technique' is the most popular. In this technique, a visual survey of the occurrence of leaf-cutting ant nests and their damage is performed to recognize the worst sites, which are used in decision-making. ${ }^{137}$ The problem is the extrapolation of the worst scenario and not the identification of the sites under justifiable control based on economic injury levels, which leads to what should be avoided - the overuse of insecticide (insecticide baits in particular). Therefore, the development of sampling plans for leaf-cutting ants is sorely needed and presents a challenge, demanding procedures that are distinct from those usually applied to agriculture pest insects and requiring a strong spatial analysis component.

The sampling focus of either injury or nest still requires definition. Although injury sampling is usually preferred when decision making (since it directly incurs in economical loss), Atta nests tend to be easier to locate and quantify with the added benefit of potentially allowing the recognition of their area of influence and minimum spacing between nests with georeferencing and distance interpolation using spatial analysis. This procedure should allow us to delimit the range and distribution of injury from different nests, directing the control effort and eventual use of economic thresholds under development for forest plantations subjected to attack by leaf-cutting ants, particularly of the genus Atta.

\subsection{New attractants for toxic baits}

The success of a toxic bait used against leaf-cutting ants is largely dependent on its attractant, and citrus extracts are the common choice in currently marketed baits; however, the mass and size of the bait granules are also important variables to consider. ${ }^{43,138,139}$ Improved bait granule mass and size can improve pick-up by ants, which may vary with the species targeted, but commercial baits retain a standardized granule and attractant (citrus extracts), which are not suitable for grass-cutting ants such as Atta capiguara (Gonçalves) and A. bisphaerica (Forel). ${ }^{139,140}$ The challenge here is the development of toxic baits for grass-cutting ants; promising alternatives have already been recognized, although some of these alternatives did not perform as desired when incorporated into baits. ${ }^{141-143}$ However, leaves of jaragua grass (Hyparrhenia rufa (Nees) Stapf) and sugar cane (Saccharum officinarum L.) showed promising results as bait attractants for $A$. bisphaerica, thus opening up relevant possibilities for grass-cutting ant species, which remains to be explored not only with insecticidal baits, but also with pathogen-contaminated baits. ${ }^{139}$

\subsection{Natural insecticides as a replacement for synthetic compounds}

The use of organo-synthetic insecticides is pervasive in toxic baits for leaf-cutting ants without any natural alternative currently available. Old synthetic compounds such as dodecachlor, which set the standard for efficacy against leaf-cutting ants, have understandably been banned or highly restricted as persistent organic pollutants. Successful successors to such compounds, however, have been targeted by the Forest Stewardship Council (FSC) in its policy on the management and certification of forest plantations. ${ }^{144}$ This European organization for the certification of forest products promotes integrated pest management and longterm monitoring of health and environmental impacts in cultivated forests and, consequently, is restricting synthetic insecticide use (including sulfluramid, fipronil, fenitrothion and the pyrehtroids $\alpha$ cypermethrin and deltamethrin) against leaf-cutting ants in these environments. ${ }^{145}$ Therefore, to secure their FSC certification status, the large reforestation companies and principle large-scale users of insecticidal baits are increasingly interested in pest sampling and monitoring in addition to seeking alternatives to the current synthetic compounds under use.

The search for new antagonistic molecules originating from toxic or repellent plants is on the increase. Since the 1980s researchers have been studying these plants but after the prohibition of dodecachlor the studies have been intensified up to the point that it can be said that there is a real 'race' in the search of new phytochemicals. The literature is very abundant on this subject. A summary of these studies can be found in Montoya-Lerma et al., ${ }^{27}$ however, it demands time, money and joint work between biologists and chemists. The search continues, but alternatives, particularly natural alternatives, are difficult to find and are not without risks and restrictions, as previously discussed. However, complex phytochemical mixtures (e.g. from unpurified plant extracts) usually have reduced risks and restrictions, ${ }^{146}$ and have been successfully subjected to small-scale use as an important leaf-cutting ant management tactic. ${ }^{27}$ 


\subsection{Pathogen-insecticide associated use}

Natural attack of entomopathogenic fungi on leaf-cutting ants seems rather rare ${ }^{147}$ despite their susceptibility in laboratory tests. ${ }^{148}$ The defensive hygienic behavior of the leaf-cutting ants, including self- and allo-grooming that spreads the ants antimicrobial secretions, certainly contributes to this effect and leads to the disappointing results that are usually obtained with the use of even high concentrations of fungal conidia against the ants. $^{149}$

The prospective use of pathogenic fungi against leaf-cutting ants has potential, but its effective field utilization remains a challenge. An interesting possibility is to associate the fungal conidia with low doses of neurotoxic insecticides. ${ }^{150}$ The reasoning behind such an approach involves the potential behavioral alteration sparked by the neurotoxic insecticide, which might impair the ants' defensive behavior against pathogen contamination. A preliminary attempt using the nicotinic acethylcholine receptor agonist imidacloprid, in association with the entomopatogenic fungus Beauveria bassiana, provided appealing results and indicated the predicted synergic action of the insecticide, which is worthy of additional attention. This combination in attractive baits could be promising and could allow the introduction of the pathogen into the nest. Such an approach should be further explored.

Another largely neglected management possibility against leaf-cutting ants, particularly Acromyrmex ants, is a tripartite approach simultaneously combining tactics against the ant, its cultivated fungus and mutualistic bacteria Pseudonorcadia (found in the exoskeleton of Acromyrmex spp). Usually a single target is emphasized in managing leaf-cutting ants, either the ant itselfor its cultivated fungus. However, the simultaneous use of compounds exhibiting insecticidal and fungicidal activity, or a mixture of an insecticide and a fungicide, may provide synergic effect increasing the control efficacy. The possibility of also simultaneously targeting Pseudonocardia strains in Acromyrmex may further potentiate ant management (targeted at the ant and its fungus) compromising an important component of the colony hygiene strategy increasing its vulnerability to insecticidal and fungicidal agents. This tripartite management approach deserves future consideration.

\section{CONCLUDING COMMENTS}

Leaf-cutting ants remain dominant species in Neotropical America, with some species having recognized pest status. Management efforts should be directed against these species when they are indeed of economic concern. Such recognition is usually neglected, leading to the overuse of predominantly insecticidal baits, which are under scrutiny and use restriction in cultivated forests. Suitable control alternatives for large-scale use against leaf-cutting ants are sorely needed, but recent advances with pathogens and insecticides aided by plant species diversification in cultivated fields are promising tactics. The development of sampling plans for leaf-cutting ants and suitable economic thresholds will allow consistent decision-making regarding ant control and is likely to lead to judicious insecticide use. We believe that these developments are more comprehensive than the restriction of current synthetic insecticides without suitable alternatives; such alternatives are difficult (and expensive) to find, given that natural compounds should also be subject to health and environmental safety scrutiny because origin is not a true determinant of toxicity and risk.

\section{ACKNOWLEDGEMENTS}

The authors would like to thank the Editorial Board of Pest Management Science for the invitation to prepare this review and A Carrick for the guidance provided. The thought-provoking comments and suggestions provided by Dr R Wilkins and two anonymous reviewers were greatly appreciated. The financial support provided by the National Council of Scientific and Technological Development (CNPq), the CAPES Foundation (Brazilian Ministry of Education), and the Minas Gerais State Foundation of Research Aid (FAPEMIG) is also greatly appreciated and acknowledged here.

\section{REFERENCES}

1 Della Lucia TMC and de Souza DJ, Importância e história de vida das formigas-cortadeiras, in Formigas-cortadeiras - da biologia ao manejo. Vol. 1, ed. by Della Lucia TMC. Editora UFV, Brazil, pp. 13-26 (2011).

2 Brandão CR, Mayhé-Nunes AJ and Sanhudo CED, Taxonomia e filogenia das formigas-cortadeiras, in Formigas-cortadeiras - da biologia ao manejo. Vol. 1, ed. by Della Lucia TMC. Editora UFV Brazil, pp. 27-48 (2011).

3 Fowler HG, Leaf-cuttings ants of the genera Atta and Acromyrmex of Paraguay (Hymenoptera Formicidae). Deutsch Entomol Z 32:19-34 (1985).

4 Wilson EO, The Insect Societies. Harvard University Press, Cambridge, MA (1971).

5 Wilson EO and Hölldobler B, Eusociality: origin and consequences. Proc Natl Acad Sci USA 102:13367-13371 (2005).

6 Wilson EO, Caste and division of labor in leaf-cutter ants (Hymenoptera: Formicidae: Atta). I. The overall pattern in Atta sexdens. Behav Ecol Sociobiol 7:143-156 (1980).

7 Fowler HG, Pagani MI, Silva AO, Forti LC, Pereira-da-Silva V and Vasconcelos $\mathrm{HL}$, A pest is a pest? The dilemma of Neotropical leafcutting ants: keystone taxa of natural ecosystems. Environ Manag 13:671-675 (1989).

8 Perfect I and Vandermeer J, Distribution and turnover rate of a population of Atta cephalotes in a tropical rain forest in Costa Rica. Biotropica 25:316-321 (1993).

9 Jones CG, Lawton JH and Shachak M, Organisms as ecosystem engineers. Oikos 69:373-386 (1994).

10 Jones CG, Lawton JH and Shachak M, Positive and negative effects of organisms as physical ecosystem engineers. Ecology 78:1946-1957 (1997).

11 Wirth R, Herz H, Ryel RJ, Beyschlag W and Hölldobler B, Herbivory of Leaf-cutting Ants. Springer-Verlag, Berlin (2003).

12 Rico-Gray $V$ and Oliveira PS, The Ecology and Evolution of Ant-Plant Interactions. University of Chicago Press, Chicago (2007).

13 Farji-Brener AG, Amador S, Chinchillaa F, Escobar S, Cabrera S, Herrera I, et al, Information transfer in head-on encounters between leafcutting ant workers: food, trail condition or orientation cues? Anim Behav 79:343-349 (2010).

14 Coutinho JM, Aspectos ecológicos da saúva no cerrado. A saúva, as queimadas e sua possível relação com a ciclagem de nutrientes minerais. Biol Zool da USP 8:1 -9 (1984).

15 Farji-Brener AG and Silva J, Leaf-cutting ant nests and soil fertility in a well-drained savanna in western Venezuela. Biotropica 27:250-253 (1995).

16 Farji-Brener AG and Illes AE, Do leaf-cutting ant nests make 'bottomup gaps' in Neotropical rain forest? a critical review of the evidence. Ecol Lett 3:219-227 (2000).

17 Moutinho P, Nepstad DC and Davidson EA. Influence of leaf-cutting ant nests on secondary forest growth and soil properties in Amazonia. Ecology 84:1265-1276 (2003).

18 Sternberg L da SL, Pinzon MC, Moreira MZ, Moutinho P, Rojas El and Herre EA, Plants use macronutrient accumulated in leaf-cutting ant nests. Proc R Soc Lond B 274:315-321 (2007).

19 Sousa-Souto L, Shoereder JH, Schaefer CEG and Silva WL, Ant nests and soil nutrient availability: the negative impact of fire. J Trop Ecol 24:639-646 (2008).

20 Leal IR and Oliveira PS, Interactions between fungus growing ants (Attini), fruits and seeds in Cerrado vegetation in Southeast Brazil. Biotropica 30:170-178 (1998). 
21 Peternelli EFO, Della Lucia TMC, Peternelli LA, Martins SV and Borges $\mathrm{EE}$, The interaction among workers of the genera Atta and Acromyrmex (Hymenoptera: Formicidae) and seeds of Mabea fistulifera (Euphorbiaceae) a pioneer tree species in Brazil. Sociobiology 42:597-603 (2003).

22 Haeder S, Wirth R, Herz H and Spiteller D, Candicinin-producing Streptomyces support leaf-cutting ants to protect their fungus garden against the pathogenic fungus Escovopsis. Proc Natl Acad Sci USA 106:4742-4746 (2009).

23 Oh DC, Poulsen M, Currie CR and Clardy J, Dentigerumicin a bacterial mediator of an ant-fungus symbiosis. Nat Chem Biol 5:391-393 (2009).

24 Benckiser G, Ants and sustainable agriculture, in Sustainable Agriculture, vol 2, ed. by E. Lichtfouse et al. Springer, Berlin (2011).

25 Mikheyev AS, History, genetics and pathology of a leaf-cutting ant introduction a case study of the Guadeloupe invasion. Biol Invasions 10:467-473 (2008).

26 Hölldobler B and Wilson EO, The Ants. Harvard University Press, Cambridge, MA (1990).

27 Montoya-Lerma J, Giraldo-Echeverri C, Armbrecht I, Farji-Brener A and Calle Z, Leaf-cutting ants revisited: towards rational management and control. Int J Pest Manag 53:225-247 (2012).

28 Oliveira MA, Araújo MS, Marinho CGS, Ribeiro MMR and Della Lucia TMC, Manejo de formigas-cortadeiras, in Formigas-cortadeiras - da biologia ao manejo. Vol. 1, ed. by Della Lucia TMC. Editora UFV, Brazil, pp. 400-419 (2011).

29 Hernández JV and Jaffé K, Dano econômico causado por populações de formigas Atta laevigata em plantações de Pinus caribaea Mor. elementos para o manejo da praga. Ann Soc Entomol Bras 24:287-298 (1995).

30 Matrangolo CAR, Castro RVO, Della Lucia TMC, Della Lucia RM, Mendes AFN, Costa JMFM, et al, Crescimento de eucalipto sob efeito de desfolhamento artificial. Pesqui Agropecu Bras 45:952-957 (2010).

31 Alipio S, Controle de formigas-cortadeiras. Normas técnicas da Pains Florestal, 8 pp. (1989).

32 Dow Agrosciences, Controle de formigas-cortadeiras. s/e. Folheto (1998).

33 Mariconi FAM, As saúvas. São Paulo Agronômica (1970).

34 Della Lucia TMC, Atta bisphaerica: uma ilustre desconhecida. Naturalia 24:53-59 (1999).

35 Anjos N, Della Lucia TMC and Mayhé-Nunes J, Guia prático sobre formigas-cortadeiras em reflorestamentos. Graffcor Itda. Ponte Nova (1998)

36 Della Lucia TMC, Hormigas de importância economica em la región Neotropical, in Introducción a las hormigas de la región Neotropical, ed. by Fernández F. Instituto. Bogotá, Colombia, pp. 337-349 (2003).

37 Della Lucia TMC and Araújo MS,. Formigas-cortadeiras: atualidades no combate, in Manejo integrado - doenças, pragas e plantas daninhas ed. by Zambolin L. Editora UFV, Viçosa, pp. 245-273 (2000).

38 Montoya-Correa M, Montoya-Lerma J, Armbrecht I and GallegoRopero MC, ¿Cómo responde la hormiga cortadora de hojas Attacephalotes (Hymenoptera: Myrmicinae) a La remoción mecânica de sus nidos? Bol Mus Entomol Universidad del Valle 8:1-8 (2007).

39 Urbas P, Araújo Jr MV, Leal IR and Wirth R, Cutting more from cut forests: edge effects on foraging herbivory of leaf-cutting ants in Brazil. Biotropica 39:489-495 (2007).

40 Fowler HG and Stiles EW, Conservative resource management by leaf-cutting ants? The role of foraging territories and trails, and environmental patchiness. Sociobiology 5:25-41 (1980).

41 Cherrett JM, Resource conservation by the leaf-cutting ant Atta cephalotes in tropical rain forest. Ecol Manag 2:253-263 (1983).

42 Rockwood LL and Hubbell SP, Host plant selection, diet, diversity, and optimal foraging in a tropical leaf-cutting ant. Oecologia 74:55-61 (1987)

43 Roces F, Leaf-cutting ants cut fragment sizes in relation to the distance from the nest. Anim Behav 40:1181-1183 (1990).

44 Kost C, de Oliveira EG, Knoch TA and Wirth R, Spatio-temporal permanence and plasticity of foraging trails in young and mature leaf-cutting ant colonies (Atta spp.). J Trop Ecol 21:677-688 (2005).

45 Kost C, Tremmel M and Wirth R, Do leaf cutting ants cut undetected? Testing the effect of ant-induced plant defences on foraging decisions in Atta colombica. PLoS ONE 6:e22340 (2011).

46 Levin DA, The chemical defenses of plants to pathogens and herbivores. Annu Rev Ecol Syst 7:121 -159 (1976).
47 Hubbell SP, Howard JJ and Wiemer D, Chemical leaf repellency to an attine ant: seasonal distribution among potential host species. Ecology 65:1067-1076 (1984).

48 Fernandéz-Martin $\mathrm{H}$, Zimmerman JK and Wcislo WT, Nest-funding in Acromyrmexoctopinosus (Hymenoptera, Formicidae, Attini): demography and putative prophylactic behaviors. Insect Soc 50:304-308 (2003).

49 Pavon L and Camargo M, Study of the mandibular glands of ant workers Atta sexdens rubropilosa (Forel, 1908) (Hymenoptera: Formicidae) focusing the ultrastructural cytochemistry. Am J Agric Biol Sci 1:27-35 (2006).

50 Magistrali IC and dos Anjos N, Avaliação de sauveiros externos em eucaliptais de Minas Gerais. Cien Flor 21:349-354 (2011).

51 Schultz TR and Brady SG, Major evolutionary transitions in ant agriculture. Proc Natl Acad Sci USA 105:5435-5440 (2008).

52 Mueller UG, Rehner SA and Schultz TR, The evolution of agriculture in ants., Science 281:2034-2038 (1998).

53 Mueller UG, Schultz TR, Currie CR, Adams RMM and Malloch D, The origin of the Attini ant fungus mutualism. J Hyg Camb 76:169-197 (2001).

54 Bacci M Jr, Solomon EE, Silva-Pinhati ACO, Mueller UG, Martins VG, Carvalho AOR, et al, Phylogeny of leafcutter ants in the genus Atta Fabricius (Formicidae: Attini) based on mitochondrial and nuclear DNA sequences. Mol Phylogenet Evol 52:427-437 (2008).

55 Fisher PJ, Stradling DJ and Pegler DN, Leaf-cutting ants, their fungus gardens and formation of basidiomata of Leucoagaricus gongylophorus. Mycologist 8:128-131 (1994).

56 Scott JJ, Budsberg KJ, Suen G, Wixon DL, Balser TC and Currie CR, Microbial community structure of leafcutter ant fungus gardens and refuse dumps. PLOS ONE 5(3):1 - 12 (2010).

57 Hart A and Ratnieks F, Task partitioning, division of labor and nest compartimentalization collectively isolate hazardous waste in the leaf-cutting ant Atta cephalotes. Behav Ecol Sociobiol 49:387-392 (2001).

58 Mueller UG, Dash D, Rabeling C and Rodrigues A, Coevolution between Attini ants and actinomycete bacteria a reevaluation. Evolution 62:2894-2912 (2008).

59 Mueller UG, Mikheyev AS, Hong E, Sen R, Warren DL, Solomon SE, et al, Evolution of cold-tolerant fungal symbionts permits winter fungi culture by leafcutter ants at the northern frontier of a tropical ant-fungus symbiosis. Proc Natl Acad Sci USA 108:4053-4056 (2011).

60 Lacerda FG, Della Lucia TMC and de Souza DJ, Biologia comportamental das operárias do lixo das colônias de formigascortadeiras, in Formigas-cortadeiras - da biologia ao manejo, ed. by Della Lucia TMC. Editora UFV, Viçosa, Brazil, pp. 226-235 (2011).

61 Lenoir A, Fresneau D, Errard C and Hefetz A, The individuality and the colonial indentity in ants: the emergence of the social representation concept in information processing, in Social Insects, ed. by Deneubourg JL and Pasteels J. Birkhäuser Verlag, Basel, pp. 219-237 (1999).

62 Currie CR, Mueller UG and Malloch D, The agricultural pathology of ant fungus gardens. Proc Natl Acad Sci USA 96:7998-8002 (1999).

63 Currie CR, Scott JA, Summerbele RC and Malloch D, Fungus-growing ants use antibiotic-producing bacteria to control garden-parasites. Nature 389:701-704 (1999).

64 Currie CR and Stuart AE, Weeding and grooming of pathogens in agriculture by ants. Proc $R$ Soc Lond B 268:1033-1039 (2001).

65 Currie CR, Bot ANM and Boomsma JJ, Experimental evidence of a tripartite mutualism: bacteria protect ant fungus gardens from specialized parasites. Oikos 101:91-102 (2003).

66 Viana AMM, Frèzard A, Malosse C, Della Lucia TMC, Errard C and Lenoir A, Colonial recognition of the fungus in fungusgrowing ant Acromyrmex subterraneus subterraneus (Hymenoptera: Formicidae). Chemoecology 11:29-36 (2001).

67 Hart A and Ratnieks F, Waste management in leaf-cutting ant Atta cephalotes. Behav Ecol 13:224-231 (2002).

68 De Souza DJ, Della Lucia TMC and Barbosa LCA, Discrimination between workers of Acromyrmex subterraneus molestans from monogynous and polygynous colonies. Braz Arch Biol Technol 49:277-285 (2006).

69 Fernández-Marín H, Zimmerman JK, Nash DR, Boomsma JJ and Wcislo WT, Reduced biological control and enhanced chemical pest management in the evolution of fungus farming in ants. Proc $R$ Soc Lond B 276:2263-2269 (2009). 
70 Armitage SAO, Broch JF, Fernández-Marín H, Nash DR and Boomsma $\mathrm{J}$, Immune defense in leaf-cutting ants a cross-fostering approach. Evolution 65:1791-1799 (2011).

71 do Nascimento RR, Schoeters E, Morgan ED, Billen J and Stradling DJ, Chemistry of metapleural gland secretions of three attine ants, Atta sexdens rubropilosa, Attacephalotes, and Acromyrmex octospinosus (Hymenoptera: Formicidae). J Chem Ecol 22:987-1000 (1996).

72 Bot ANM, Ortius-Lechner D, Finster K, Maile R and Boomsma $\mathrm{JJ}$, Variable sensitivity of fungi and bacteria to compounds produced by the metapleural glands of leaf-cutting ants. Insect Soc 49:363-370 (2002).

73 Fernández-Marín H, Zimmerman JK, Rehner SA and Wcislo WT, Active use of metapleural glands by ants in controlling fungal infection. Proc R Soc Lond B 273:1689-1695 (2006).

74 Bollazzi M and Roces F, Control of nest water losses through building behavior in leaf-cutting ants. Insect Soc 57:267-273 (2010).

75 Farji-Brener AG and Tadey M, Trash to treasure: leaf-cutting ants repair nest-mound damage by recycling refuse dump materials. Behav Ecol 23:1195-1202 (2012)

76 Lacerda FG, Della Lucia TMC, Pereira OL, Peternelli ELA and Tótola MR, Mortality of Atta sexdens workers in contact with colony waste from different plant sources. Bull Entomol Res 109:99-103 (2010).

77 Lacerda FG, Della Lucia TMC, Serrão JE, Secon DR, Souza LM and De Souza DJ, Morphometry of the metapleural gland of workers engaged in different behavioral tasks in the ant Atta sexdens rubropilosa. Anim Biol 60:229-236 (2010).

78 Bot A, Currie CR, Hart AG and Boomsma JJ, Waste management in leaf-cutting ants. Ethol Ecol Evol 13:225-237 (2001).

79 Ballari S, Farji-Brener AG and Tadey M, Waste management in the leafcutting ant Acromyrmex lobicornis: divisions of labor, aggressive behavior, and location of external refuse dumps. J Insect Behav 20:87-98 (2007)

80 Gavaghan J, The bug society: scientists excavate underground ant city that rivals the Great Wall of China' with a labyrinth of highways. Daily Mail, Feb 2 (2012).

81 Fowler HG, Forti LC, Pereira-da-Silva V and Saes NB, Economics of grass-cutting ants, in Fire Ants and Leaf-cutting Ants: Biology and Management, ed. by Lofgren CS and Vander Meer RK. Westview Press, Boulder, CO, pp. 28-35 (1986).

82 Buhl J, Gautrais J, Deneubourg J, Kuntz P and Theraulaz G, The growth and form of tunneling networks in ants. J Theor Biol 243:287-298 (2006).

83 Moreira MD, Picanço MC, Barbosa LCD, Guedes RNC, de Campos MR, Silva GA, et al, Plant compounds insecticide activity against Coleoptera pests of stored products, Pesqu Agropecu Bras 42:909-915 (2007)

84 Kleineidam $C$ and Roces F, Carbon dioxide concentrations and nest ventilation in nests of the leaf-cutting ant Atta wollenveideri. Insect Soc 47:241-248 (2000).

85 Jiménez J and Decaëns T, Chemical variations in the biostructures produced by soil ecosystem engineers. Examples from the Neotropical savannas. Eur J Soil Biol 42:S92-S102 (2006).

86 Bollazzi M, Kronenbitter J and Roces F, Soil temperature, digging behavior, and the adaptive value of nest depth in South American species of Acromyrmex leaf-cutting ants. Oecologia 158:165-175 (2008).

87 Forti LC, Moreira AA, Andrade APP, Castellani MA and Cadalto N, Nidificação e arquitetura de ninhos de formigas-cortadeiras, in: Formigas-cortadeiras - da biologia ao manejo. Vol. 1, ed. by Della Lucia TMC. Editora UFV, Brazil, pp. 102-125 (2011).

88 Zanetti R, Zanuncio JC, Souza-Silva A and Abreu LG de, Eficiência de isca formicida aplicada sobre o monte de terra solta de ninhos de Atta sexdens rubropilosa (Hymenoptera: Formicidae). Rev Árvore 27:407-410 (2003)

89 Anjos N, Sistema 'Arrastão' para combate a formigas cortadeiras, in 21st Simpósio de Mirmecologia, UFOP, Ouro Preto (MG, Brazil), p. 101 (2009).

90 Zanetti R, Zanuncio JC, Mahyé-Nunes AJ, Medeiros AGB and Souza-Silva A, Combate sistemático de formigas-cortadeiras com iscas granuladas em eucaliptais com cultivo mínimo. Rev Árvore 27:387-392 (2003).

91 Souza A, Zanetti R and Calegario N, Nível de dano econômico para formigas-cortadeiras em função do índice de produtividade florestal de eucaliptais em uma região de mata atlântica. Neotrop Entomol 40:483-488 (2011).
92 Cruz AP, Zanuncio JC, Zanetti R and Gomes OS, Eficiência de iscas granuladas à base de sulfluramida e de clopirifós no controle de Atta sexdens sexdens (Hymenoptera: Formicidae), no trópico úmido. Acta Amazon 26:145-150 (1996).

93 Zanuncio JC, Cruz AP, Santos DF and Oliveira MA, Eficiência da isca Mirex-S (sulfluramida 0,3\%) no controle de Attacephalotes (Hymenoptera: Formicidae) em três dosagens. Acta Amazon 26:115-120 (1996)

94 Zanuncio JC, Zanuncio TV, Pereira JMM and Oliveira HN, Controle de Atta laevigata (Hymenoptera: Formicidae) com iscas LandrinF, em área anteriormente coberta com Eucalyptus. Ciênc Rural 29:573-576 (1999).

95 Zanetti R, Zanuncio JC, Souza-Silva A, Mendonça LA, Mattos JOS and Rizental MS, Eficiência de produtos termonebulígenos no controle de Atta laevigata (Hymenoptera: Formicidae) em plantio de eucalipto. Ciênc Agrotec 32:1313-1316 (2008).

96 Almeida AF, Alves JEM and Mendes Filho JMA, Manutenção do subbosque em florestas de Eucalyptus urophyla e a distribuição regular de portas-isca, visando o controle preventivo de saúvas (Atta spp.). Silvicultura 8:142-144 (1983).

97 Zanuncio JC, Batalha VC, Guedes RNC and Picanço M, Insecticide selectivity to Supputius cincticeps (Stal) (Het.: Pentatomidae) and its prey Spodoptera frugiperada (J.E. Smith) (Lep.: Noctuidae). J Appl Entomol 122:457-460 (1998).

98 Zanetti R, Jaffé K, Vilela EF, Zanuncio JC and Leite HG, Efeito da densidade e do tamanho de sauveiros sobre a produção de madeira em eucaliptais. Ann Soc Entomol Bras 29:105-117 (2000).

99 Howarth FG, Environmental impacts of classical biological control. Annu Rev Entomol 36:485-509 (1991).

100 Simberloff $D$ and Stiling P, Risks of species introduced for biological control. Biol Conserv 78:185-192 (1996).

101 Louda SM, Pemberton RW, Johnson MT and Follett PA, Nontarget effects - the Achilles' heel of biological control? Retrospective analyses to reduce risk associated with biocontrol introductions. Annu Rev Entomol 48:365-396 (2003).

102 Bigler F, Babendreier D and Kuhlmann U, Environmental Impact of Invertebrates for Biological Control of Arthropods: Methods and Risk Assessment. CABI, Wallingford, UK (2006).

103 Bragança MAL, Parasitoides de formigas-cortadeiras, in Formigascortadeiras - da biologia ao manejo. Vol. 1, ed. by Della Lucia TMC. Editora UFV, Brazil, pp. 321-343 (2011).

104 Guillade A and Folgarait PJ, Life history traits and parasitism rates of four phorid species (Diptera: Phoridae), parasitoids of Atta vollenweideri leaf-cutter ants (Hymenoptera: Formicidae) in Argentina. J Econ Entomol 104:32-40 (2011).

105 Bragança MAL, Tonhasca A Jr and Della Lucia TMC, Reduction in the foraging activity of the leaf-cutting ant Atta sexdens caused by the phorid Neodohrniphora sp. Entomol Exp Appl 89:305-311 (1998).

106 Bragança MAL, Tonhasca AJ and Moreira DDO, Parasitism characteristics of two phorid fly species in relation to their host, the leaf-cutting ant Atta laevigata (Smith) (Hymenoptera: Formicidae). Neotrop Entomol 31:241-244 (2002).

107 Bragança MAL, Tonhasca AJ and Della Lucia TMC, Características biológicas e comportamentais de Neodohrniphoraelongata Brown (Diptera: Phoridae), um parasitoide da saúva Atta sexdens rubropilosa Forel. Rev Bras Entomol 53:600-606 (2009).

108 Elizalde L and Folgarait PJ, Behavioral strategies of phorid parasitoids and responses of their hosts, the leaf-cutting ants.J Insect Sci 12:135 (2012)

109 López E, Romero M, Ortíz A and Orduz S, Primer registro de Metarhizium anisopliae infectando reinas de Attacephalotes (Hymenoptera: Formicidae) em Colombia. Rev Colom Entomol 25:49-56 (1999).

110 Verma M, Brar SK, Tyagi RD and Vaerol JR. Antagonistic fungi, Trichoderma spp.: panoply of biological control. Biochem Eng J 37:1-20 (2007).

111 Boareto MAC and Forti LC, Perspectiva de formigas-cortadeiras. Serie técnica IPEF 11:31-46 (1997).

112 United Nations Environmental Programme (UNEP), Montreal Protocol on Sustances that Deplete the Ozone Layer. 1994 Report of the Methyl Bromide Technical Options Committee. 1995 assessment, Nairobi, Kenya (1995).

113 Forti LC, Della Lucia TMC and Wassu WK, Metodologias para experimentos com iscas granuladas para formigas cortadeiras, 
in As formigas cortadeiras, ed. by Della Lucia TMC. Folha de Viçosa, Brazil, pp. 191-211 (1993).

114 Souza LF, As formigas cortadeiras e o seu combate por meio de iscas granuladas. Bol Campo 18:5-6 (1962).

115 Della Lucia TMC and Vilela EF, Métodos atuais de controle e perspectivas, in As formigas cortadeiras, ed. by Della Lucia TMC. Folha de Viçosa, Brazil, p. 190 (1993).

116 Gallo D, Nakano O, Silveira Neto S, Carvalho RPL, Batista GC, Berti Filho E, et al, Manual de Entomologia Agrícola, 2nd ed. Ceres, São Paulo, Brazil (1988)

117 Antunes EC, Guedes RNC, Della Lucia TMC and Serrão JE, Sublethal effects of abamectin suppressing colonies of the leafcutting ant Acromyrmex subterraneus subterraneus. Pest Manag Sci 56:1059-1064 (2000)

118 Antunes AC, Della Lucia TMC, Guedes RNC and Serrão JE, Abamectindriven alterations on queen ovaries of the leaf-cutting ant Acromymex subterraneus subterraneus (Hymenoptera: Formicidae). Sociobiology 45:163-172 (2005).

119 Isman MB, Botanical insecticides, deterrents, and repellents in modern agriculture and an increasingly regulated world. Annu Rev Entomol 51:45-66 (2006).

120 Rosell G, Quero C, Coll J and Guerrero A, Biorational insecticides in pest management. J Pestic Sci 33:103-121 (2008).

121 Boulogne I, Petit P, Ozier-Lafontaine H, Desfontaines L and LorangerMerciris $G$, Insecticidal and antifungal chemicals produced by plants a review. Environ Chem Lett 10:325-347 (2012).

122 Boulogne I, Germonsen-Robineau L, Ozier-Lafontaine H, Jacoby-Koaly C, Aurela L and Loranger-Merciris G, Acromyrmexoctospinosus (Hymenoptera:formicidae) management. Part 1: effects of TRAMIL's insecticidal plant extracts. Pest Manag Sci 68:313-320 (2012).

123 Boulogne I, Ozier-Lafontaine H, Germonésn-Robineau L, Desfontaines $L$ and Loranger-Merciris G, Acromyrmexoctospinosus (Hymenoptera: formicidae) management: effects of TRAMIL's fungicidal plant extracts. J Econ Entomol 105:1224-1233 (2012).

124 Schoereder JH, Silva HMM, Carvalho AF and Muscardi DC, Proposed lime stone treatment as pest control fails for the leaf-cutting ant Atta sexdens rubropilosa. Crop Protect 42:79-82 (2012).

125 Coats JR, Risk from natural versus synthetic insecticides. Annu Rev Entomol 39:489-515 (1994).

126 Arthropod Pesticide Resistance Database, Search (2013) http://www.pesticideresistance.com/display.php?page-species\& arld-472 [accessed 19 April 2013].

127 North RD, Howse PE and Jackson CW, Agonistic behavior on the leaf-cutting ant Atta sexdens rubropilosa elicited by caryophyllene. JInsect Behav 13:1-13 (2000).

128 Marsaro AL Jr, Souza RC, Della Lucia TMC, Fernandes JB, Silva MFGF and Vieira PC, Behavioral changes in workers of the leaf-cutting ants Atta sexdens rubropilosa induced by chemical compounds of Eucalyptus maculata leaves. J Chem Ecol 30:1771 -1780 (2004).

129 Marinho CGS, Della Lucia TMC, Guedes RNC, Ribeiro MMR and Lima ER, $\beta$-Eudesmol induced aggression in the leaf-cutting ant Atta sexdens rubropilosa. Entomol Exp Appl 117:89-93 (2005).

130 Marinho CGS, Ribeiro MMR, Della Lucia TMC and Guedes RNC, Aggressive response of pest ant species to $\beta$-eudesmol (Hymenoptera: Formicidae). Sociobiology 47:445-454 (2006).

131 Marinho CGS, Della Lucia TMC, Ribeiro MMR, Magalhães STV, Guedes RNC and Jham GN, Interference of $\beta$-eudesmol in nestmate recognition in Atta sexdens rubropilosa (Hymenoptera: Formicidae). Bull Entomol Res 98:467-473 (2008).

132 Robinson SW and Cherrett JM. The possible use of methylpirrole-2carboxilate, an ant trail pheromone, as a component of an improved bait for leaf-cutting ant (Hymenoptera: Formicidae). Bull Entomol Res 68:159-170 (1978).

133 Robinson SW and Cherrett JM, Laboratory investigations to evaluate the possible use of brood pheromones of the leaf-cutting ant
Atta cephalotes $(\mathrm{L})$ as a component in an attractive bait. Bull Entomol Res 63:519-529 (1974).

134 Vilela EF and Howse PE, Pheromone performance as an attractive components in baits for the control of the leaf-cutting ant Atta sexdens rubropilosa (Hym: Formicidae). Ann Soc Entom Bras 17:107-124 (1988).

135 Zanuncio JC, Lopes ET, Leite HG, Zanetti R, Sediyama CS and Fialho MCQ, Sampling methods for monitoring the number area of colonies of leaf-cutting ants (Hymenoptera: Formicidae) in Eucalyptus plantations in Brazil. Sociobiology 44:337-344 (2004).

136 Cantarelli EB, Costa EC, Zanetti R and Pezzutti R, Plano de amostragem de Acromyrmex spp. (Hymenoptera: Formicidae) em áreas de préplantio de Pinus spp. Ciênc Rural 36:385-390 (2006).

137 Anjos N, Moreira DDO and Della Lucia TMC, Manejo integrado de formigas-cortadeiras em reflorestamentos, in As formigas cortadeiras, ed. by Della Lucia TMC. Folha de Viçosa, Brazil, pp. 212-241 (1993).

138 Oliveira MC, Della Lucia TMC, Nascimento D Jr and Lima CA, Espécies forrageiras preferidas para o corte por Atta bisphaerica Forel, 1908 (Hymenoptera: Formicidae). Rev Ceres 49:321-328 (2002).

139 Lima CA, Della Lucia TMC, Guedes RNC and Veiga CE, Desenvolvimento de iscas granuladas com atraentes alternativos para Attabisphaerica Forel (Hymenoptera: Formicidae) e sua aceitação pelas operárias. Neotrop Entomol 32:497-501 (2003).

140 Forti LC and Boaretto MAC, Seleção de substratos, na forma de isca granulada, para formigas cortadeiras de gramíneas Atta capiguara Gonçalves e Attabisphaerica Forel (Hymenoptera: Formicidae). Naturalia 24:249-251 (1999).

141 Boaretto MAC, Forti LC, Moreira AA, Bueno OC and Fernandes JB, Seletividade de Atta capiguara Gonçalves e Atta bisphaerica Forel (Hymenoptera: Formicidae) por extratos orgânicos de gramíneas em campo. Naturalia 24:175-177 (1999).

142 Boaretto MAC, Forti LC, Bueno OC and Fernandes JB, Seteletividade de Atta capiguara Gonçalves e Atta bisphaerica Forel (Hymenoptera: Formicidae) por iscas granuladas contendo extratos orgânicos de gramíneas forrageiras em campo. Naturalia 24:179-181 (1999).

143 Santos JL, Moreira AA, Boaretto MAC, Andrade APP, Forti LC, Bueno OC, et al, Seletividade e Atta bisphaerica Forel, 1908, por extratos hexânicos de gramíneas, em laboratório. Naturalia 24:85-187 (1999).

144 Forest Stewardship Council, FSC-GUI-30-001 a VI-0 EN, Approved derogations for use of 'highly hazardous' pesticides. FSC (2010).

145 Isenring Rand Neumeister L, Recommendations Regarding Derogations to Use Alpha-Cypermethrin, Deltamethrin, Fenitrothion, Fipronil and Sulfluramid in FSC Certified Forests in Brazil (2010).

146 Arnason JT, MacKinnon S, Durst A, Philogene BJR, Hasbun C, Sanchez $P$, et al, Insecticides in tropical plants with non-neurotoxic modes of action. Recent Adv Phytochem 27:107-113(1993).

147 Hughes DP, Evans HC, Hywel-Jones N, Boomsma JJ and Armitage SAO, Novel fungal disease in complex leaf-cutting ant societies. Ecol Entomol 34:214-220 (2009).

148 Santos AV, Lorenz B and Samuels RI, Selection of entomopathogenic fungi for use in combination with sublethal doses of imidacloprid: perspectives for the control of the leaf-cutting ant Atta sexdens rubropilosa Forel (Hymenoptera: Formicidae). Mycopathologia 163:233-240 (2007).

149 Diehl-Fleig E, Silva ME da, Specht A and Valim-Labres ME, Efficiency of Beauveria bassiana for Acromyrmex spp. control (Hymenoptera: Formicidae). Ann Soc Entomol Bras 22:281 - 285 (1993).

150 Galvanho JP, Carrera MP, Moreira DDO, Erthal M Jr, Silva CP and Samuels RI, Imidacloprid inhibits behavioral defenses of the leafcutting ant Acromyrmex subterraneus subterraneus (Hymenoptera: Formicidae). J Insect Behav 26:1-13 (2013). 